\title{
Study on the Application of Educational Games in the Teaching of English Creative Practice
}

\author{
HuDan \\ Nanchang Institute of Science \&Technology, Nanchang 330108, China
}

Keywords: Innovative practice, Primary and secondary school students, Educational games, Practical skills.

Abstract. In the era of information explosion, information technology is affecting people's way of life. The $21^{\text {st }}$ century is the era of knowledge-based economy, knowledge economy will occupy the leading position in the world economic development based on knowledge and information, dissemination and application, in this context, education information has become an inevitable trend. With the rapid development of information technology, internets are gradually popular, and the young people are addicted to computer games, affecting the learning and life of young people. Educational experts suggest that the course of teaching adds some games to improve students' learning interest, so the concept of educational games came into being. Based on the characteristics of educational games and educational value, this paper carries out innovation practice reform in primary and secondary schools, changing the traditional teaching methods, enhancements' learning interest, improving students' learning efficiency, increasing students' practical skills and professional skills.

\section{Introduction}

Under the influence of economic globalization and the internet, English has become the world's language. In recent years, the rapid development of information and network, speeds up the popularization of the multimedia technology, making the educational games should be used as a possible, and education games begin to become a hot topic in the educational world [1-3]. Relevant departments calls for the development of learning English green games, blending entertainment and education as a whole can improve the boring learning, but also increase the learning of entertainment. In this paper, how to combine educational games with English, we can go through innovative reform to solve the problems of English learning and improve students' practical ability.

\section{Overview of Educational Games}

Games, as the name implies, generally refers to the way of entertainment, but also refers to the process of the activities, and the general will have physical and mental stimulation [4]. Games are divided into two kinds of games and activities, the former mainly includes chess, cards, mahjong and other leisure games; the latter includes chase and the special assistant way of activities, there are certain circumstances and rules, which have the nature of competition.

Education game is a more serious game, it is generally aimed at a kind of education needs and development. The development is the purpose of education, the actual need to use reliable educational theory as a support point, so that students access to the corresponding education knowledge, so as to achieve the function of the product $[5,6]$. The education carries out the game, increasing the game entertainment part in a happy education. The relationship of educational games is shown in Figure 1.

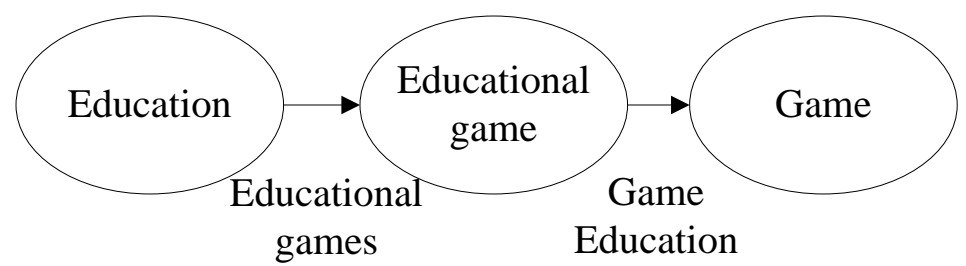

Fig.1 Education game relationship diagram 
Education game is a combination of education and game practice application. In order to better meet the needs of users, we generally need to find a suitable point, namely a dynamic balance, making education content and game content are appropriate as far as possible, not only to show the role of the game, but also to achieve the purpose of education.

\section{The Purpose of English Practical Teaching}

Through the rich educational games activities, the purpose of English practical teaching is to increase the students' English learning interest, to strengthen the classroom knowledge, to enrich learning and extracurricular activities, to develop students' English language basic skills, especially the ability of English expression that mainly includes the consolidation of basic knowledge, improving oral English pronunciation and English expression ability [7-9].

(1) The consolidation of basic knowledge

According to the survey statistics of education ministry, more than $70 \%$ of the primary and middle school students in China are weak in English. In the national English teaching, the basic knowledge includes vocabulary, phrases collocation and grammar knowledge, it has always been the key to English learning, and the core strength of the ability must have the core strength. Learning good English have enough basic knowledge, so as to have enough resources in the follow-up study can be called at any time. Therefore, English practice teaching is that the most fundamental purpose is let students to accumulate basic knowledge, to master textbook vocabulary, phrase collocation and grammatical knowledge, to memorize English words and sentence patterns.

(2) Improving spoken pronunciation

Oral English is an important factor in the process of English teaching. Pure pronunciation can give a good impression, but in practice, oral English is the biggest difficulty of the students. Phonogram pronunciation is not accurate, the students do not want to say and not pronunciation, those are a common feature of primary and middle school students. Having good spoken English ability can give students enough confidence, but also can give students more opportunities to communicate. Therefore, we want to improve the students' pronunciation in the practice of English teaching, so that students should pay attention to oral English training, to cultivate students' pure english.

(3) Improving English communication skills

For the presentation of communication skills, people not only should master a foreign language performance, but also embody a person's quality and charm. Oral communication has always been the most important way for people to obtain information, so he most important is the exchange of dialogue in the process of using English; another important goal is to improve students' communicative ability in English innovation and practice education, so that students can communicate with each other without obstacles.

\section{The Status Quo of English Practical game Education}

English game teaching practice is the theme of English teaching, to cultivate students' pronunciation, master the basic knowledge of grammar, understand the western culture and improve the learning self-confidence as the purpose [10-12]. The development of the entertainment game is a kind of English practical education in education game, it is also perfect combination of games and english.

English educational games have generally game and education, in which the game is mainly refers to the competition, purpose and rules of educational games. Education refers that the educational games include the teaching objective, learning content and teaching quality feedback and other content.

At present, English educational games mainly have the flash games role-playing and flash games, English games mainly include English exercises, diaries, word games, oral communication and other characteristics, important is ordinary English education system with the words function, the user can establish their words and increase the English vocabulary according to their English level. The functional interface of the word again and again is shown in Figure 2 and Figure 3. 


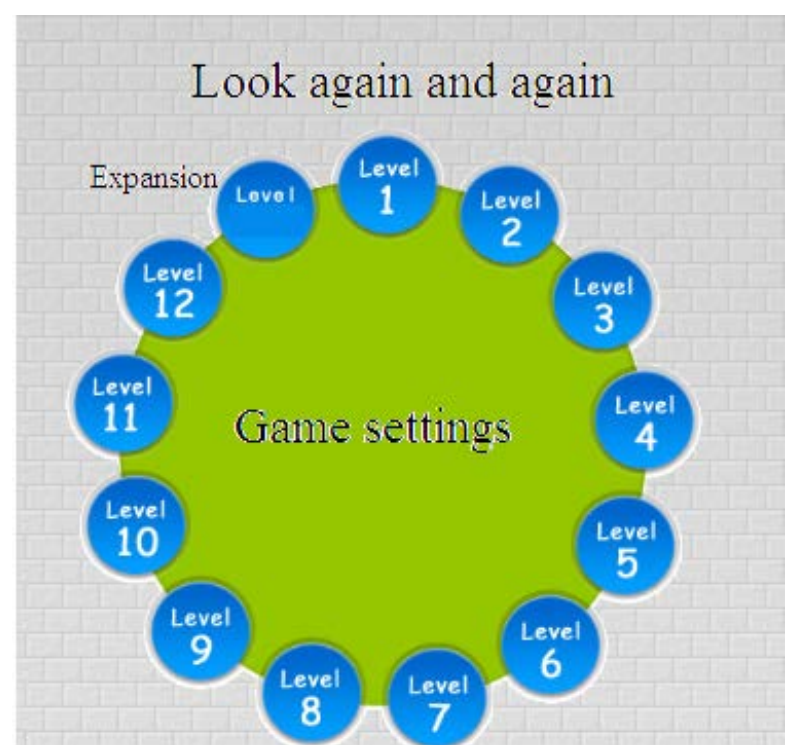

Fig. 2 Word again and again look interface

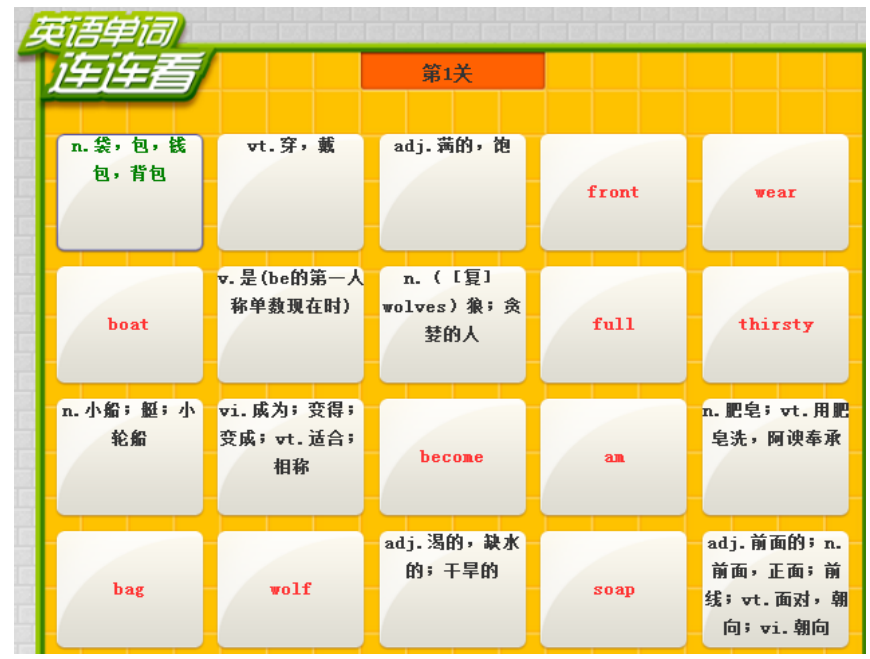

Fig. 3 Word again and again look game

\section{The Design of Educational Games Phonogram Innovation Teaching in English}

Spoken English is the most critical in learning English, but we want to have fluent and pure English, learning the phonogram is the key. Because of China's provinces and heavy accent, English teacher level is not hign, outstanding teachers are less in remote areas, and students' spoken English ordinary is very low [13]. Therefore, this paper designs the teaching scheme of learning English phonetic, playing phonetic game with English applies the classroom, to improve the students' oral English ability.

Tis paper designs the teaching program for the first grade of junior high school, the object is class phonetic pronunciation and want to further learning phonetic symbols' 20 students, the program mainly goes through the way of questionnaire survey, we can get feedback information from the class teacher and the students. The teaching plan is carried out in the form of extra-curricular, and it is not required to take up students' class time. Scheme design is as follows:

The teaching time is two months, the teaching mainly includes" international English phonetic alphabet", "play with English "phonetic part, phonetic practice games and other resources; teaching form is self-oriented students after class, the English teachers weekly carry out inspection and guidance for the 20 students learning situation

Content: learning English phonogram pronunciation.

Objective: to accurately read 48 phonetic, consolidate English basic knowledge, improve students' oral English pronunciation, improve students' English ability communicate and enhance the 
confidence of students.

Key: phonogram recognition and pronunciation.

Difficulty: Double vowel pronunciation.

Process: to divide into four stages.

First stage: Phonogram pronunciation test before teaching.

Second stage: after class, students play phonetic game 20 minutes every day in a month, they can learn six vowels and sevent consonants, and they can watch international phonetic alphabet video to consolidate learning in the last few days.

Third stage: after class, students play phonetic game 20 minutes and repeat the speech materials every day in a month, rfocusing on the study of phonetic accent pronunciation rules and keeping watching the international phonetic alphabet video.

Fourth stage: we can carry out phonogram pronunciation test after the teaching and detection learning effect.

Before practice teaching, first of all to take part in the curriculum students carry out pronunciation test and score as shown in Figure 4. After practice teaching, the 20 students carry out phonogram pronunciation test again, the phonogram test results after teaching are shown in Figure 5.

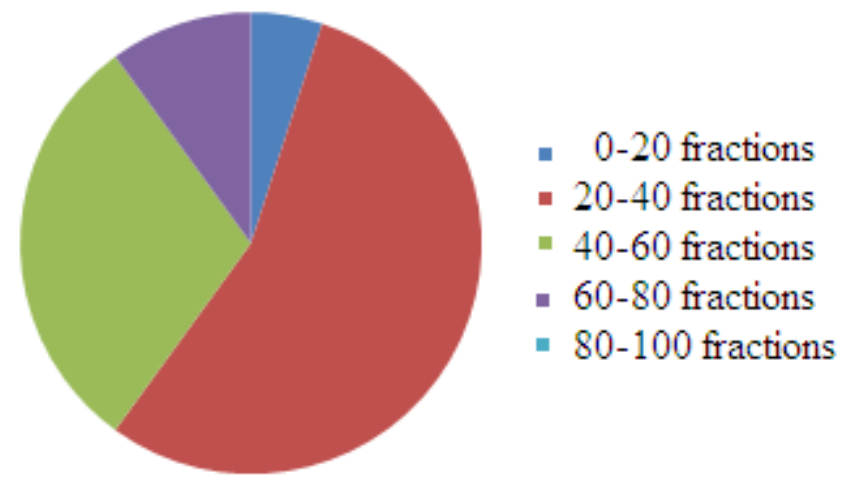

Fig.4 Phonogram test results before teaching

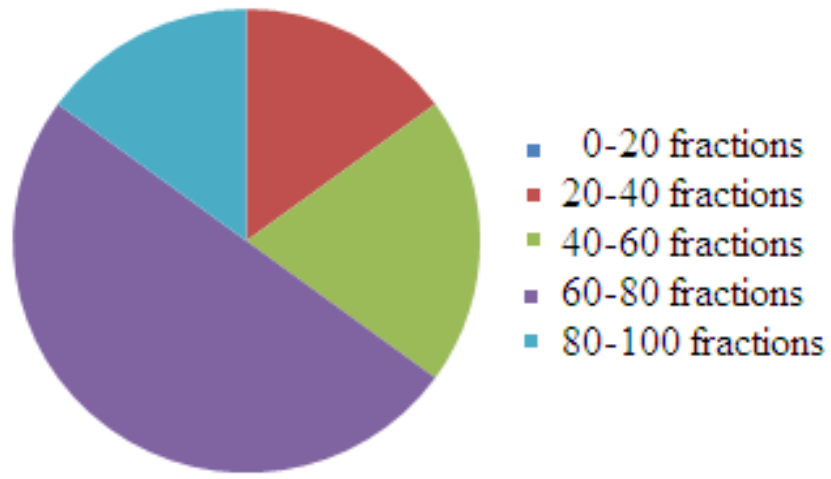

Fig.5 Phonogram test results after teaching

In order to prove the effect of the teaching program, the results of the two tests will be compared as shown in Figure 6. 


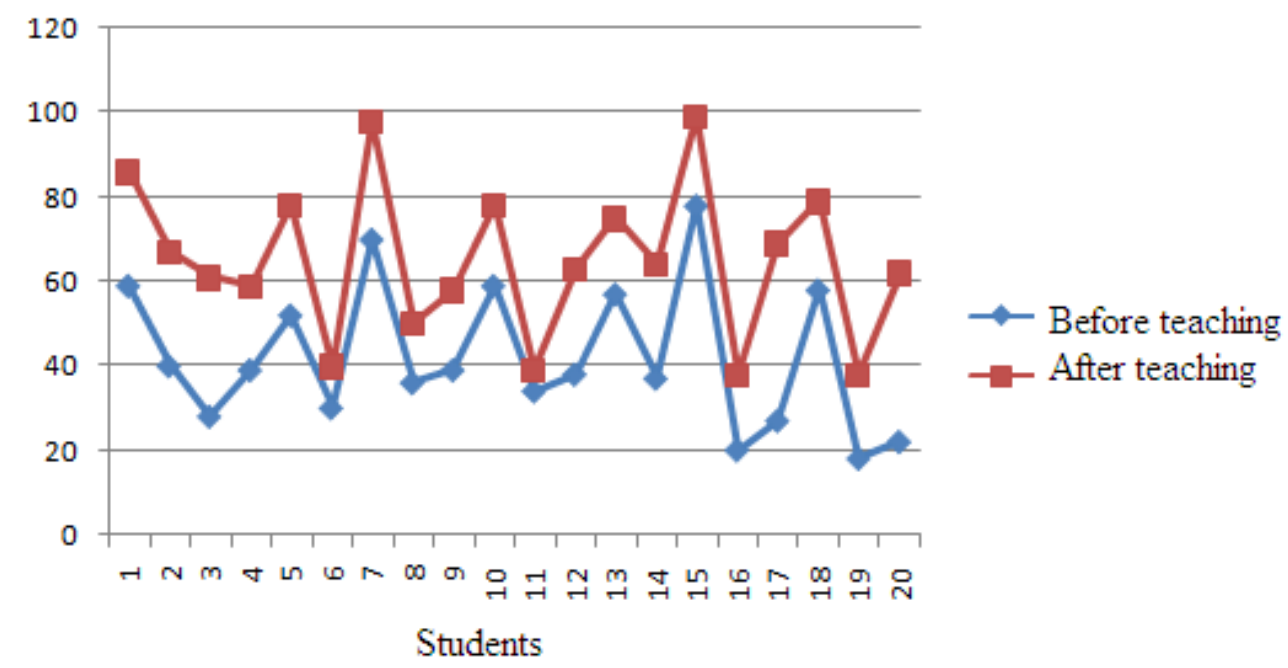

Fig. 6 The comparison results of phonogram tests before and after teaching

As shown in Figure 6, the use of extra-curricular time studies English phonetic practice education courses. After two months, 20 students phonetic pronunciation ability significantly enhanced and significantly improved the students self-confidence, it is proved that the educational games are very outstanding in the advantage of English teaching practice.

\section{Summary}

Entertainment Games bring happiness to people, the game will be applied to teaching, students will happy learn, so that they not only can improve students' learning interest, but also can develop the students' mental and intellectual. Based on educational games, this paper studies the teaching scheme of English innovation practice. Practice has proved that the combination of games and education can cultivate students' learning interest and improve their self-confidence. Educational games can bring good learning atmosphere, which can provide a rich nutrition and good humanistic environment for the construction of harmonious society.

\section{References}

[1] Z.Q. Liu, H.M. Wan, B.J. Gu. Education game thinking. China modern educational equipment, 2014(7):171-172.

[2] Y. Zhao. The feasibility analysis of our country English education gamen the primary and middle schools. Basic education research, 2013(22): 21-23.

[3] H.Y. Sun. Design and application of educational games in primary school English classroom teaching. Sichuan Normal University, 2013: 1-12.

[4] B.J. Wang, H. Zhu. Research on the application of educational games in primary school English teaching. Electronic production, 2015(16): 55-56.

[5] M.J. Zhang. The application of educational games in primary English teaching. Qufu Normal University, 2013: 21-27.

[6] W.N. Mao. Research on the design strategy of primary school English teaching game based on RETAIN model. Henan Normal University, 2014: 2-13.

[7] Q.L. Liu. Application of educational games in primary school English teaching based on template. East China Normal University, 2014: 1-11.

[8] Wang G.J. The application of educational games in English teaching. Shanghai international studies University, 2014: 1-9. 
[9] Y. Gao. How to use educational games on improving the effectiveness of primary school science teaching. Education, 2014(11): 85-87.

[10] J.Z. Cui. Research on the application of network education game in the teaching. Shandong Normal University, 2013: 2-13.

[11] X.M. Li. Analysis of the application of Flash games in the classroom teaching of secondary vocational English. Journal of Jiamusi Education Institute, 2013(7): 337-339.

[12] Q. Fan. The application of eEducational games in the teaching of English. Shaanxi Normal University, 2013: 2-12.

[13] X.L. Sun. Research on weak schools English game teaching in rural areas. GanNan Normal University, 2014:3-11. 